\section{ESQUISTOSSOMOSE EM \\ PERNAMBUCO: DETERMINANTES \\ BIO-ECOLÓGICOS E SÓCIO- \\ CULTURAIS EM COMUNIDADE DE \\ PEQUENOS AGRICULTORES DA ZONA DA MATA}

Os programas de controle das endemias, no Brasil, não têm conseguido eficiencia nas suas ações, nem mesmo estando instrumentalizados com tecnologias eficazes.

A lógica clássica, intervencionista e medicalizada das ações programáticas está centrada no ataque sistemático ao caramujo vetor e ao parasito, num total descompromisso social para com as comunidades assistidas.

Compreende-se assim, o interesse e o compromisso ético da pesquisa em saúde pública em proceder a estudos onde os eventos ligados ao processo saúde/doença das comunidades fossem abordados com uma concepção estrutural de causas, integrando investigação e participação social.

Dentro desta perspectiva articulada, merecem destaque como atributos causais não só os determinantes biológicos, mas também os sociais e ainda o componente cultural na sua dimensão histórica e representações simbólicas.

A área de estudo escolhida foi a comunidade agrícola de Natuba, situada a cerca de $100 \mathrm{~km}$ do Recife, localidade endêmica para esquistossomose e com estrutura político/comunitária organizada.

Foi realizado um estudo epidemiológico de corte transversal para avaliar os fatores de risco para esquistossomose, associando variáveis sócio-econômicas, sanitárias e comportamentais (quantificáveis), com a prevalência e intensidade da infecção.

Uma segunda abordagem, de cunho antropológico e etnográfico, permitiu resgatar, do imaginário coletivo, a construção cultural da esquistossomose e analisar os macro e micro determinantes sócio-culturais do processo saúde/doença.

Os resultados do inquérito epidemiológico informam que a comunidade possui condições

Recebido para publicação em 17/03/97.

\section{SCHISTOSOMIASIS IN PERNAMBUCO STATE, BRAZIL: BIOECOLOGICAND SOCIOCULTURAL DETERMINANTS IN A SMALL RURAL COMMUNITY OF ZONA DA MATA}

The control of endemic diseases has not attained the desirable effectiveness in spite the use of modern efficient thecnologies. The classic interventionist approach for the control of schistosomiasis centered in systematic fighting of the snail hosts combined to large scale medical treatment, is usually carried out without social preocupation due to the assisted communities.

It is easily understandable the interest and the ethical compromisse of public health research while producing studies in which the health/disease process is looked according to structural conception of causes. In this case, investigation and social participation should be integrated.

Under this perspective, the biological and social determinants, as well as the cultural components, should be remembered in compass to the historical dimensions and symbolic representations.

"Natuba", a small rural community, distant $100 \mathrm{~km}$ from Recife, was selected for the current study. It is a schistosomiasis endemic area holding a political/communitary well organized structure.

Epidemiological methods were used to detect the dependent variables (those related to the human infection) and the independent variables (demographic, economic, sanitary and social).

This part of the study was carried out by means of a house-to-house survey covering the whole population.

Another methodological approach of anthropological/etnographic nature, allowed better comprehension of the collective imaginary, the schistosomiasis cultural construction, and the analysis of the macro and micro socio-cultural determinants of the health/disease process.

Results of the epidemiological survey shows that the studied community has social economic levels more stable than the population living in others rural areas of Pernambuco state. The great majority of Natuba,s house have showers and latrines $(90,0 \%)$ : in spite of this favorable health 
Resumo de Tese. Barbosa CCGS. Esquistossomose em Pernambuco: determinantes bio-ecológicos e sócioculturais em comunidade de pequenos agricultores da Zona da Mata. Revista da Sociedade Brasileira de Medicina Tropical 30:347-348, jul-ago, 1997.

sócio-econômicas mais estáveis em relação às populações da zona rural de Pernambuco. A maioria das casas possue banheiros com fossas (90.0\%), mas, apesar deste indicador, a prevalência para S. mansoni foi de $35.1 \%$.

A análise estatística univariada identificou tres variáveis (faixa etária, escolaridade e número de contatos) que mostraram associação significativa com a positividade para

S. mansoni. Os resultados da análise multivariada realizada a seguir, permitiram a seleção dos fatores causais e das variáveis de confundimento, entre aquelas previamente identificadas.

$\mathrm{Na}$ discussão dos resultados, o diagnóstico epidemiológico quantitativo é discutido criticamente, com embasamento no estudo qualitativo etnográfico, quanto às condições ambientais de risco (contaminação, transmissão) e práticas de risco (econômicas e comportamentais) envolvidas na conformação e manutenção da estrutura endêmica.

O que se pretendeu, ao final deste estudo, foi fazer a articulação do conhecimento da doença esquistossomótica nas suas várias dimensões ou níveis determinantes. Esta compreensão mútua, por parte dos pesquisadores e dos pesquisados, sobre os processos que intervêm na dinâmica de transmissão, permitiu a identificação de elementos relevantes para a construção conjunta de ações programáticas de controle dessa endemia, a nível local, com reflexos bem mais abrangentes para a saúde como um todo. indicators the schistosomiasis prevalence rate was $35,1 \%$.

Univariate statistical analysis indicated that three variable (age, schooling and number of water contacts) are significantly associated to schistosomiasis infection. The multivariate analysis allowed the selection of causal factors and the determination of the confounding variables.

The quantitative epidemiological diagnosis is critically discussed in comparison to the ethnographic qualitative study. This discussion was based on the environmental risk conditions (contamination, transmission) and risk practices (economics and behavioural), both components of the shaping and maintenance of the endemic structure.

At the final part of this study, an articulation of the knowledge on the various dimensions or determinant levels of the schistosomiasis disease is made. Mutual comprehention, between researchers and people under investigation, on the dinamic transmission process would be relevant for a joint construction, at local level, of programmatic actions for the control of schistosomiasis. This would extend reflexions on the health/disease process as a whole.

\section{Constança Clara Gayoso Simões Barbosa}

Tese apresentada à Escola Nacional de Saúde

Pública da Fundação Oswaldo Cruz para

obtenção do Título de Doutor.

Rio de Janeiro, RJ, Brasil 1996 